Abstracta Iranica Abstracta Iranica

Revue bibliographique pour le domaine irano-aryen

Volume 32-33 | 2013

Comptes rendus des publications de 2009-2010

\title{
Stephen E. Hess. Islam, local elites, and Chinas's missteps in integrating the Uyghur Nation
}

\section{Alexandre Papas}

\section{OpenEdition}

1 Journals

\section{Édition électronique}

URL : http://journals.openedition.org/abstractairanica/40788

DOI : 10.4000/abstractairanica.40788

ISSN : 1961-960X

Éditeur :

CNRS (UMR 7528 Mondes iraniens et indiens), Éditions de l'IFRI

\section{Édition imprimée}

Date de publication : 1 décembre 2013

ISSN : 0240-8910

\section{Référence électronique}

Alexandre Papas, «Stephen E. Hess. Islam, local elites, and Chinas's missteps in integrating the Uyghur Nation », Abstracta Iranica [En ligne], Volume 32-33 | 2013, document 301, mis en ligne le 01 juillet 2016, consulté le 26 septembre 2020. URL : http://journals.openedition.org/abstractairanica/ 40788 ; DOI : https://doi.org/10.4000/abstractairanica.40788

Ce document a été généré automatiquement le 26 septembre 2020

Tous droits réservés 


\section{Stephen E. Hess. Islam, local elites, and Chinas's missteps in integrating the Uyghur Nation}

\section{Alexandre Papas}

\section{RÉFÉRENCE}

Stephen E. Hess. « Islam, local elites, and Chinas's missteps in integrating the Uyghur Nation ». Orta Asya ve Kafkasya Araștırmaları, 4/7, 2009, p. 75-96.

1 Fondé sur quelques sources secondaires, exclusivement en anglais, cet article explique les contradictions de la politique chinoise envers la minorité ouïgoure au Xinjiang. Difficile de trouver une quelconque originalité dans cette étude si ce n'est l'attention qu'elle prête aux élites bureaucratiques ouïgoures et à leur rôle d'intermédiaires entre la société et l'état. Au-delà du simple constat, il reste à en faire la sociologie.

\section{AUTEURS}

\section{ALEXANDRE PAPAS}

CNRS, Paris 